\title{
ANALISIS EFISIENSI TEKNIS PADA USAHA SAPI PERAH DI KECAMATAN TANJUNGSARI
}

\section{ANAL YSIS OF TECHNICAL EFFICIENCY ON DAIRY FARMING IN TANJUNGSARI DISTRICTS}

\author{
Annisa Wanda Utami*1, Lia Budimulyati Salman², Achmad Firman ${ }^{3}$ \\ ${ }^{1}$ Unpad, J1. Saluyu C6/H2 No. 278 Riung Bandung \\ ${ }^{2}$ Unpad, Komp. DPRDI Kav. No. 62 Margasari Bandung 40286 \\ ${ }^{3}$ Unpad, Jl. Graha Asih Blok A 1 No. 23 Bandung \\ *E-mail: awandautami@gmail.com \\ (Diterima 13-12-2019; Disetujui 17-01-2020)
}

\begin{abstract}
ABSTRAK
Usaha sapi perah telah menjadi usaha turun temurun sebagai usaha keluarga. Usaha sapi perah di Indonesia umunya masih merupakan usaha sapi perah rakyat dengan skala kepemilikan di bawah 10 ekor per peternak. Masalah utama yang sampai saat ini masih dihadapi yaitu belum efisiennya peternak dalam usaha sapi perah. Berdasarkan masalah tersebut, penelitian ini bertujuan untuk mengetahui nilai efisiensi teknis usaha sapi perah, faktor produksi yang dapat meningkatkan atau menurunkan produksi susu, dan mengetahui faktor inefisiensi pada usaha sapi perah. Penelitian dilakukan pada usha sapi perah rakyat di Kecamatan Tanjungsari pada bulan Agustus-September 2019 di wilayah KSU Tandangsari. Pengambilan data dilakukan dengan metode survei menggukana kuesioner. Analisis dilakukan menggunakan software Frontier 4.1. Hasil analisis menunjukkan ratarata nilai efisiensi teknis usaha sapi perah pada daerah penelitian yaitu 0,643. Faktor-faktor produksi yang dapat mempengaruhi produksi susu yaitu jumlah sapi laktasi, pemberian hijauan, pemberian konsentrat, dan curahan tenaga kerja. Faktor yang diduga dapat mempengaruhi ienfisiensi diantaranya umur, pengalaman, pendidikan, sapi non produktif, total populasi, dummy pekerjaan utama, dan produksi rumput walaupun secara statistic belum signifikan. Berdasarkan nilai efisiensi teknis tersebut mengindikasikan bahwa usaha sapi perah di Kecamatan Tanjungsari belum efisien secara teknis $(\mathrm{Et})<1(0,643)$.
\end{abstract}

Kata kunci: Efisiensi, Faktor Produksi, Frontier, Usaha Sapi Perah

\section{ABSTRACT}

The dairy cow business has become a regeneration business as a family business. The dairy cow business in Indonesia is generally still a people's dairy cow business with a scale of ownership under 10 per farmer. The main problem that is still faced today is the inefficiency of farmers in the dairy business. Based on these problems, this study aims to determine the value of the technical efficiency of dairy cattle businesses, factors of production that can increase or decrease milk production, and determine the inefficiency factors in dairy cattle businesses. The study was conducted on the people's dairy cows in Tanjungsari District in August-September 2019 in the KSU area of Tandangsari. Data is collected by the survey method using a questionnaire. The analysis was performed using Frontier 4.1 software. The results of the analysis show the average value of the technical efficiency of the dairy cattle business in the study area is 0.643 . The factors of production that can affect milk production are the number of lactation cows, foraging, concentrating, and labor. Factors that are thought to affect efficiency include age, experience, education, non-productive cattle, total population, main occupational dummy, and grass production, although not statistically significant. Based on the value of the technical efficiency indicates that the dairy cow business in Tanjungsari District has not been technically efficient $(\mathrm{Et})<1(0.643)$.

Keywords: Efficiency, Production Factors, Frontier, Dairy Cattle Business 


\section{PENDAHULUAN}

Usaha sapi perah merupakan salah satu kegiatan peternakan yang masih dilakukan oleh sebagian peternak di beberapa wilayah di Indonesia. Data statistik menunjukkan bahwa populasi sapi perah di Indonesia sebanyak 550.141 ekor meningkat jika dibandingkan dengan sepuluh tahun yang lalu. Walaupun terjadi peningkatan populasi jika dibandingkan dengan sepuluh tahun yang lalu, populasi sapi perah dan produksi susu diperkirakan mengalami penurunan dari tahun ke tahun. Hal ini dapat dilihat dari tingkat impor produksi susu yang semakin tinggi setiap tahun, pada tahun 2016 tingkat kebutuhan susu masyarakat Indonesia 79\% masih impor dari luar negeri sampai tahun 2017, $82 \%$ kebutuhan susu masuh diimpor dari luar negeri.

Penurunan populasi dan produksi susu juga dialami oleh peternak anggota KSU Tandangsari. Turunnya produksi susu dan populasi sapi laktasi, serta peternak banyak yang berhenti berusaha dikarenakan oleh banyak faktor, terutama yang bersifat on farm, sepetri pakan, kualitas bibit, ketersediaan tenaga kerja dan lain sebagainya. Pola pemeliharaan yang saat ini masih tradisional berimplikasi pada rendahnya efisiensi. Berdasarkan penelitian terdahulu di
Provinsi Jawa Barat yang diwakili oleh Kecamatan Pangalengan dan Lembang serta Provinsi Jawa Timur yang diwakili oleh Kecamatan Grati dan Tutur menunjukkan tingkat efisiensi usaha peternakan sapi perah rakyat dengan skala kepemilikan sapi laktasi $\leq 5$ ekor menunjukkan rata-rata kisaran efisiensi teknis sebesar 0,79 yang masih menunjukkan kondisi decreasing retrun to scale (Asmara, Purnamadewi, \& Lubis, 2016). Rendahnya efisiensi menandakan belum optimalnya pengunaan faktorfaktor produksi dan rendahnya produksi susu. Melalui diketahuinya tingkat efisiensi pengunaan faktor-faktor produksi tersebut maka akan dapat dirumuskan kebijakan untuk peningkatan efisiensi sehingga diharapkan dapat meningkatkan pendapatan peternak sapi perah.

\section{METODE PENELITIAN}

Metode penelitian dilakukan dengan metode survei yang dilakukan di Kecamatan Tanjungsari yang merupakan wilayah kerja dari KSU Tandangsari. Responden dipilih melalui propotional sampling dimana pengembalian sampel diambil secara acak dari setiap kelompok, dimana setiap perah dan terdapat koperasi sapi perah yaitu KSU Tandangsari 
Responden dipilih melalui propotional sampling. Pengembalian sampel diambil secara acak dari setiap kelompok, dimana setiap anggota populasi mempunyai peluang yang sama untuk dipilih menjadi anggota sampel, sehingga metode ini sering disebut prosedur yang terbaik dengan cara stratified random sampling setelah itu dari setipa subpopulasi ini secara acak dimabil anggota sampelnya (Umar, 2005).

Untuk menghitung berapa jumlah sampel yang diambil acak untuk masingmasing subpopulasi dihitung dengan rumus slovin. Jumlah sampel dihitung dengan rumus slovin yaitu 79 responden dengan proporsi masing-masing kelompok Mekar Asih 23 orang, Raharja I 15 orang, Raharja II 18 orang, dan Wibawa Mekar 23 orang. Teknik pengumpulan data meliputi data primer dan data sekunder.

Metode analisis yang digunakan dalam penelitian ini adalah Stochastic Frontier Analysis yang memberikan gambaran tentang estimasi dan fungsi persamaan Stokastik Frontier dalam menganalisis tentang efisiensi usaha yang paling optimal. Karakteristik dari fungsi produksi frontier yaitu adanya simpangan $\left(v_{\mathrm{i}}-u_{\mathrm{i}}\right)$ yang terdiri dari dua bagian, yaitu komponen simetrik yang memungkinkan keragaman acak dari frontier $\left(v_{\mathrm{i}}\right)$, dan komponen satu sisi (one-sided) dari simpangan yang menangkap pengaruh inefisiensi $\left(u_{\mathrm{i}}\right)$. Fungsi tersebut dapat dipresentasikan sebagai berikut (Coelli, 1996).

$$
\text { Yit }=\operatorname{xit} \beta+(\text { Vit-Uit }) ; i=1
$$

Dimana:

Yit : Produksi yang dihasilkan usaha sapi perah-i pada waktu-t.

Xit : Vektor masukan (input) yang digunakan usaha sapi perah-i pada waktu-t.

$\beta \quad$ : Vektor parameter yang diestimasi.

Vit : Variabel acak yang berkaitan dengan faktor eksternal.

Uit : Variabel acak yang diasumsikan mempengaruhi tingkat inefisiensi teknis dan berkaitan dengan faktorfaktor eksternal.

Tabel 1. Pengertian Variabel Independen yang Digunakan

\begin{tabular}{|c|c|c|c|}
\hline No & Variabel & Unit & Definisi \\
\hline 1 & $\begin{array}{l}\mathrm{X}_{1} \text { Jumlah } \\
\text { induk laktasi }\end{array}$ & Ekor & $\begin{array}{l}\text { Jumlah sapi laktasi } \\
\text { dalam }\end{array}$ \\
\hline 2 & $\begin{array}{l}\mathrm{X}_{2} \\
\text { Pemberian } \\
\text { Hijauan }\end{array}$ & $\mathrm{Kg}$ & $\begin{array}{l}\text { Jumlah pemberian } \\
\text { hijauan yang } \\
\text { diberikan }\end{array}$ \\
\hline 3 & $\begin{array}{l}\mathrm{X}_{3} \text { Pakan } \\
\text { Konsentrat }\end{array}$ & $\mathrm{Kg}$ & $\begin{array}{l}\text { Jumlah pemberian } \\
\text { konsentrat }\end{array}$ \\
\hline 4 & $\begin{array}{l}\text { Curahan } \\
\text { Tenaga Kerja }\end{array}$ & $\mathrm{HOK}$ & $\begin{array}{l}\text { Curahan tenaga } \\
\text { kerja peternak }\end{array}$ \\
\hline
\end{tabular}

Tabel 1, merupakan pengertian variabel independen yang digunakan pada efisiensi teknis dengan satuan unit yang digunakan pada masing-masing variabel. 
Variabel independen tersebut terdiri atas jumlah induk sapi laktasi, pemberian hijauan, pakan konsentrat, dan curahan tenaga kerja. Dimana variabel-variabel independen tersebut yang akan dioperasikan dengan output yaitu produksi susu untuk mendapatkan nilai efisiensi teknis. Sedangkan untuk model inefisiesni teknis pada usaha sapi perah dijelaskan sebagai berikut:

$\mu_{\mathrm{i}}=\delta_{0}+\delta_{1} \mathrm{Z}_{\mathrm{Ii}}+\delta_{2} \mathrm{Z}_{2 \mathrm{i}} \ldots \ldots+\delta_{\mathrm{n}} \mathrm{Z}_{\mathrm{ni}}+\theta_{\mathrm{it}}$

Dimana:

$\mu_{\mathrm{i}} \quad$ : efek inefisiensi teknis

$\delta \quad$ : nilai koefisien yang diharapkan

$\mathrm{Z}_{\mathrm{i} . . .} \mathrm{Zn}$ : Faktor yang diasumsikan untuk menjelaskan inefisiensi

$\theta_{\mathrm{i}} \quad$ : Error, diasumsikan independent dan distribusi secara identik $\mathrm{N}(0$, $\left.\sigma^{2} \theta\right)$.

Tabel 2. Variabel Pada Efek Inefisiensi Teknis

\begin{tabular}{clc}
\hline No & \multicolumn{1}{c}{ Variabel } & Unit \\
\hline 1 & $Z_{1}$, Umur & Tahun \\
2 & $Z_{2}$, Pengalaman & Tahun \\
3 & $Z_{3}$, Pendidikan & Tahun \\
4 & $Z_{4}$, Sapi non produktif & Ekor \\
5 & $Z_{5}$, Total populasi & Ekor \\
6 & $Z_{6}$, Dummy pekerjaan & Dummy \\
& utama & \\
7 & $Z_{7}$, Produksi rumput & Ton \\
\hline
\end{tabular}

Tabel 2 memberikan informasi mengenai faktor-faktor yang dapat mempengaruhi inefisiensi. Variabel tersebut terdiri atas umur, pengalaman, pendidikan, sapi non produktif, total populasi, dummy pekerjaan utama, dan produksi rumput. Variabel-variabel tersebut akan digunakan untuk mengetahui variabel mana saja yang diduga dapat mempengaruhi nilai inefisiensi teknis usaha sapi perah.

\section{HASIL DAN PEMBAHASAN}

\section{a. Karakteristik Responden}

Responden berjumlah 79 orang yang berasal dari beberapa desa di Kecamatan Tanjungsari diantaranya yaitu desa Cikahuripan, Cinanjung, Gunung Manik, Margajaya, dan Raharja yang terdiri atas dusun Babakansirna, Banyusari, Cikandang Keusal, Cikeusal, Ciluluk, Citulampa, Gordah, Lembang, Sadang, Sirahcai, dan Sukamantri. Karakteristik responden terdapat pada Tabel 3, karakteristik responden diantaranya jenis kelamin, rentang usia, pengalaman beternak, dan pendidikan terakhir responden.

Pada Tabel 3 menggambarkan bahwa peternak sapi perah di Tanjungsari didominasi oleh laki-laki yaitu sebesar $91,1 \%$, tetapi walaupun didominasi oleh laki-laki kaum perempuan sudah memiliki peran sebagai pemilik usaha sapi perah di Tanjungsari. Peternak di Tanjungsari didominasi oleh peternak berusia 36-50 tahun, di mana usia tersebut termasuk ke dalam penduduk usia kerja dan usia 
produktif. Hal ini dapat berdampak positif pada pengembangan usaha sapi perah dimana peternak yang memiliki usaha sapi perah merupakan peternak dengan usia produktif.

Tabel 3. Karakteristik Responden

\begin{tabular}{clcc}
\hline No & Karakteristik & $\begin{array}{c}\text { Jumlah } \\
\text { Responden }\end{array}$ & Presentase \\
\hline 1 & Jenis Kelamin & & \\
& Laki-laki & 72 & $91,1 \%$ \\
& Perempuan & 7 & $8,9 \%$ \\
2 & Rentang Usia & & \\
& 20-35 & 10 & $12,7 \%$ \\
& 36-50 & 40 & $50,6 \%$ \\
& 51-65 & 26 & $32,9 \%$ \\
& $66-80$ & 3 & $3,8 \%$ \\
3 & Pengalaman & & \\
& Beternak & & \\
& $\geq 5$ tahun & 9 & $11,4 \%$ \\
& 6-10 tahun & 9 & $11,4 \%$ \\
& $11-15$ tahun & 14 & $17,7 \%$ \\
\hline \multirow{4}{*}{ 16-20 tahun } & 18 & $22,8 \%$ \\
& $21-25$ tahun & 11 & $13,9 \%$ \\
& $\leq 25$ tahun & 18 & $22,8 \%$ \\
Pendidikan & & \\
Terakhir & & \\
SD & 49 & $62,0 \%$ \\
SMP & 14 & $17,7 \%$ \\
SMA & 14 & $17,7 \%$ \\
S1 & 2 & $2,5 \%$ \\
\hline
\end{tabular}

\section{b. Estimasi Fungsi Produksi Menggunakan Model Stochastic Frontier}

Estimasi fungsi produksi dihitung menggunankan model Stochastic Frontier untuk mengetahui nilai efisiensi teknis usaha sapi perah. Stochastic Frontier Analysis merupakan salah satu metode yang digunakan untuk mengeistimasi batas produksi (frontier) dan juga mengukur tingkat efisiensi produksi (Coelli, 1996). Pada penelitian ini variabel yang digunakan untuk mengestimasi fungsi produksi tersebut yaitu produksi susu, jumlah sapi laktasi, hijauan yang diberikan, dan tenaga kerja yang dicurahkan dalam pemeliharaan selama satu bulan.

Tabel 4. Karakteristik Produksi Peternakan Kecamatan Tanjungsari Per Bulan

\begin{tabular}{clcccc}
\hline No & Variabel & Min & Max & Avg & Sd \\
\hline 1 & $\begin{array}{l}\text { Prod. } \\
\text { Susu } \\
\text { (liter) }\end{array}$ & 119 & 2.432 & 681,64 & 491,59 \\
2 & $\begin{array}{l}\text { Sapi } \\
\text { laktasi } \\
\text { (ekor) }\end{array}$ & 1,0 & 7,0 & 2,32 & 1,24 \\
3 & $\begin{array}{l}\text { Hijauan } \\
\text { (kg) }\end{array}$ & 390 & 5600 & 1723,80 & 1106,79 \\
4 & $\begin{array}{l}\text { Konsentr } \\
\text { at (kg) }\end{array}$ & 170 & 1759 & 521,68 & 331,85 \\
5 & $\begin{array}{l}\text { Tenaga } \\
\text { kerja } \\
\text { (HOK) }\end{array}$ & 15 & 54,24 & 34,71 & 8,95 \\
\hline
\end{tabular}

Tabel 4, mengginformasikan otput dan input salama satu bulan yang diduga untuk menduga nilai efisiensi teknis. Ratarata produksi susu peternak di Tanjungsari yaitu 681,64 liter selama satu bulan dengan rata-rata satu hari produksi yaitu sebesar 9,69 liter/ekor. Artinya produksi susu sapi perah di Tanjungsari masih dibawah kemampuan produksi yaitu sebesar 15-20 liter/hari (Yusdja, 2005).

Karakteristik input yang digunakan yaitu jumlah sapi laktasi yang berkisar antara 1-7 ekor/peternak, masih dibawah 10 ekor per peternak. Usaha sapi perah yang ekonomis terjadi apabila setiap ekor sapi produktif atau laktasi hanya dibebani 0,40 ST (Satuan Ternak) sapi perah non 
produktif (Siregar \& Kusnadi, 2004).

Peningkatan pemberian hijauan dan peningkatan tenaga kerja dapat meningkatakan produksi susu (Binici, Zualuf, Ozel, Sevinc, \& Isgin, 2013).

Estimasi likelihood fungsi produksi maksisum dengan menggunakan Frontier 4.1 tertera pada Tabel 5 .

Tabel 5. Estimasi Likelihood Fungsi Produski Maximum- Menggunakan Frontier 4.1

\begin{tabular}{lcccc}
\hline Variabel & $\begin{array}{c}\text { Para- } \\
\text { meter }\end{array}$ & $\begin{array}{c}\text { Koef- } \\
\text { isien }\end{array}$ & Se & t-Ratio \\
\hline Constanta & $\beta_{0}$ & 2,34 & 1,109 & $2,123 * * *$ \\
$\mathrm{X}_{1}$ & $\beta_{1}$ & 0,367 & 0,174 & $2,101 * * *$ \\
$\mathrm{X}_{2}$ & $\beta_{2}$ & 0,235 & 0,126 & $1,863 * *$ \\
$\mathrm{X}_{3}$ & $\beta_{3}$ & 0,556 & 0,135 & $4,133^{* * *}$ \\
$\mathrm{X}_{4}$ & $\beta_{4}$ & $-0,256$ & 0,171 & $-1,492 *$ \\
\hline
\end{tabular}

Nilai log likelihood metode MLE $\quad-32,90$

Nilai log likelihood metode OLS $\quad-37,83$

Rataan Indeks Efisiensi $\quad 0,643$

Keterangan: $* * *=$ Nyata pada taraf $95 \%$

$* *$ = Nyata pada taraf $90 \%$

$*$ = Nyata pada taraf $80 \%$

Fungsi produksi terdiri atas jumlah sapi laktasi, pemberian hijauan, pemberian konsentrat, dan curahan tenaga kerja (HOK). Berdasarkan analisis koefisien menunjukkan tanda yang positif artinya peningkatan jumlah sapi laktasi, pemberian hijauan, dan pemberian hijauan dapat meningkatkan produksi susu pada usaha sapi perah yang dijlankan oleh responden. Setiap peningkatan input produksi secara parsial (caribus paribus) sebanyak $1 \%$ yang terdiri atas jumlah sapi laktasi, pemberian hijauan, dan pemberian hijauan dapat meningkatkan presentase produksi susu berdasarkan besarnya masing-masing nilai koefisien.

Setiap $1 \%$ peningkatan jumlah sapi laktasi berdasarkan analisis dapat meningkatkan produksi susu 0,367\%. Jumlah produksi susu yang dihasilkan pada setiap usaha sapi perah bergantung pada jumlah induk laktasi dan manajemen usahanya (Astuti, Widiati, \& Suranindyah, 2012).

Pada pemberian hijauan setiap $1 \%$ peningkatan pemberian hijauan berdasarkan analisis dapat meningkatkan produksi susu sebesar $0,235 \%$ dan peningkatan pemberian $1 \%$ konsentrat dapat meningkatkan produksi susu sebesar 0,556\%. Selain kualitas, jumlah pemberian pakan untuk setiap ekor ternak/hari juga harus diketahui agar kebutuhan zat gizi untuk mencapai kemampuan berproduksi susu yang tinggi dapat terpenuhi (Nurhayu, Ella, \& Sariubang, 2017).

Berbeda dengan jumlah sapi laktasi, pemberian pakan hijauan, dan pakan konsentrat pada jumlah tenaga kerja menunjukkan tanda negatif artinya berdasarkan analisis peningkatan 1\% pakan konsentrat dapat menurukan produksi susu sebesar $0,256 \%$. Hal ini mengindikasikan usaha sapi perah di Kecamatan Tanjungsari dalam 
penggunaan tenaga kerja sudah mulai berelebihan terutama pada tenaga kerja kelurga karena mayoritas peternak di Kecamatan Tanjungsari menggunakan tenaga kerja keluarga.

Berdasarkan batasan yang ditetapkan USDA bahwa pertanian keluarga memproduksi outputnya untuk dijual maupun untuk memenuhi kebutuhan keluarga sendiri, sedangkan tenaga kerja berasal dari dalam keluarga dan dari luar (hider labor) (Syahyuti, 2016). Terlalu banyak tenaga kerja dan waktu yang dialokasikan dengan rendahnya produksi justru akan menurunkan produktivitas dan efisiensi usaha tersebut.

Tabel 6. Distribusi Nilai Efisiensi Teknis Pada Usaha Sapi Perah di Kecmatan Tanjungsari

\begin{tabular}{|c|c|c|c|}
\hline No & ЕT\% & $\begin{array}{c}\text { Jumlah } \\
\text { Peternak }\end{array}$ & $\begin{array}{l}\text { \%Total } \\
\text { Peternak }\end{array}$ \\
\hline 1 & $0,200-0,509$ & 20 & 25,3 \\
\hline 2 & $0,510-0,809$ & 42 & 53,2 \\
\hline 3 & $0,810-0,999$ & 17 & 21,5 \\
\hline & Total & 79 & $100 \%$ \\
\hline
\end{tabular}

\section{c. Faktor yang Mempengaruhi Inefisiensi Teknis}

Inefisiensi teknis merupakan model skotastik frontier dimana efek inefisiensi $\left(u_{\mathrm{i}}\right)$ dinyatakan sebagai fungsi eksplisit dari variabel khusus dan kesalahan acak (Coelli, 1996). Variabel $\left(u_{\mathrm{i}}\right)$ berfungsi untuk menangkap efek inefisiensi teknis yang menggambarkan komponen galat (error) yang sifatnya internal. Variabel yang digunakan untuk mengetahui inefisinesi tersebut tertera pada Tabel 2. Variabel tersebut diantaranya yaitu umur, pengalaman, pendidikan, sapi non produktif, populasi, dummy pekerjaan utama, dan produksi rumput.

Tabel 7. Estimasi Faktor-Faktor Inefisiensi Pada Usaha Sapi Perah

\begin{tabular}{ccccc}
\hline No & Parmeter & Koefisien & Se & $\begin{array}{c}\mathrm{t}- \\
\text { Ratio }\end{array}$ \\
\hline 1 & $\delta_{0}$ & 1,155 & 0,628 & 1,184 \\
2 & $\delta_{1}$ & $-0,0108$ & 0,013 & $-0,83$ \\
3 & $\delta_{2}$ & 0,0078 & 0,014 & 0,556 \\
4 & $\delta_{3}$ & $-0,0463$ & 0,049 & $-0,94$ \\
5 & $\delta_{4}$ & $-0,1406$ & 0,151 & $-0,94$ \\
6 & $\delta_{5}$ & 0,0632 & 0,084 & 0,747 \\
7 & $\delta_{6}$ & $-0,275$ & 0,294 & $-0,93$ \\
8 & $\delta_{7}$ & 0,0137 & 0,025 & 0,554 \\
\hline
\end{tabular}

Berdasarkan hasil pengamatan menunjukkan bahwa variabel yang mendukung inefisiensi yaitu pengalaman dan total populasi. Artinya semakin berpengalaman peternak mengindikasikan usaha tersebut menjadi inefisiensi, hal ini bisa terjadi karena responden yang memiliki pengalaman lebih lama pada usaha sapi perah berada pada usia lanjut (late adopter) sehingga kemungkinan sulit untuk menangkap inovasi dan pengetahuan baru mengenai pemeliharaan sapi perah.

Pendidikan berdasarkan analisis dapat mengurangi nilai efisiensi. Semkain tinggi pendidikan dapat meningkatkan nilai efisiensi (Binam, Tonyè, Wandji, Nyambi, \& Akoa, 2004). Pendidikan akan 
berpengaruh dalam pengambilan keputusan yang penting dalam suatu usaha. Tingkat pendidikan juga akan berdampak pada kemauan dan kemampuan petani atau peternak dalam mencar informasi tentang penggunaan faktor produksi (Sukiyono, 2016).

Pada variabel jumlah populasi juga dapat meningkatkan nilai inefisiensi pada penelitian ini namun secara statistika tidak signifikan. Produksi rumput juga dapat meningkatkan nilai inefisiensi hal ini diduga bisa terjadi diakernakan luas lahan yang digunakan tidak selamanya digunakan untuk menanam rumput dan pada musim kemarau kemungkinan produksi rumput berkurang. Distribusi nilai efisiensi berdasarkan total populasi tertera pada Tabel 8 .

Tabel 8. Distribusi Nilai Efisiensi Berdasrkan Total Populasi

\begin{tabular}{ccccc}
\hline \multirow{2}{*}{ No } & \multirow{2}{*}{ Ratio Efisiensi } & \multicolumn{3}{c}{ Ratio Populasi (ekor) } \\
\cline { 3 - 5 } & & $2-5$ & $6-10$ & $11-15$ \\
\hline 1 & $0,1000-0,2500$ & 1 & 0 & 0 \\
2 & $0,2501-0,5000$ & 13 & 4 & 2 \\
3 & $0,5001-0,7500$ & 19 & 11 & 1 \\
4 & $0,7501-1,0000$ & 18 & 8 & 2 \\
\hline & Total & 51 & 23 & 5 \\
\hline
\end{tabular}

Seperti yang tertera pada Tabel 8 , bahwa responden dengan skala kepemilikan 2-5 memiliki rasio nilai efisiensi teknis yang hampir sama dengan rasio kepemilikan lebih dari 10 ekor. Hal ini menandakan bahwa tidak selamanya jumlah populasi dapat meningkatkan nilai efisiensi, walaupun tidak signifikan secara statistik.

Sejalan denggan hasil tersebut berdasarkan penelitian terdahulu bahwa menunjukkan peternak berskala kecil lebih efisiensi secara teknik dibandingkan dengan peternak berskala besar dan peternak berskala sedang memiliki nilai efisiensi teknis yang lebih besar dibandingkan dengan skala kecil dan besar (Johansson, 2005).

Dari kedua variabel tersebut menandakan bahwa jumlah populasi belum tentu menjadi ukuran dalam peningkatan nilai efisiensi tetapi hal ini belum tentu terjadi pada usaha peternakan di lokasi yang berbeda karena setiap usaha dan wilayah mungkin memiliki karakteristik yang berbeda.

Berbeda dengan pengalaman dan total populasi pada variabel umur, pendidikan, sapi non produktif, dummy pekerjaan utama dan produksi rumput dapat menurunkan nilai inefisiensi walaupun tidak signifikan secara statistik.

Peternak pada usia produktif (15-59 tahun) biasanya memiliki waktu lebih lama untuk belajar dan menjadi lebih berpengalaman dalam mengatur usahanya, sehingga mereka bisa menjadi lebih efisien dibandingkan dengan peternak yang berusia muda (Lachaal, 
Chahtour, \& Thaber, 2002). Efisiensi meningkat pada peternak berusia sampai 50 tahun sedangkan di luar 50 tahun nilai efisiensi menurun (Girma, 2019).

Pendidikan yang semakin tinggi dapat meningkatkan keahlian dan adopsi terhadap teknologi. Peternak yang memiliki pendidikan lebih tinggi akan lebih mudah dalam mengadopsi teknolgi. Peternak dengan tingkat pendidikan yang lebih baik akan menujukkan teknis produksi yang lebih baik dari pada peternak yang memiliki pengetahuan lebih rendah (Saptati, 2016).

Keberadaan sapi non produktif tidak selamanya menurukan nilai efisiensi walaupun tidak signifikan dapat menurunkan nilai inefisiensi. Sapi non produktif pada penelitian ini termasuk sapi dara yang sedang bunting. Sapi dara yang sedang bunting akan menjadi replacement stock setelah melewati masa kebuntingan, sehingga akhirnya nilai inefisensi dapat menurun setelah sapi non produktif menjadi sapi produktif.

Variabel dummy pekerjaan utama menunjukkan tanda yang negatif atau bertolak belakang dengan inefisiensi. Sehingga dapata dikatan pekerjaan utama sebagai peternak sapi perah mengurangi nilai inefisiensi. Peternak yang paling efisien memiliki keterkaitan dengan sumber utama pendapatannya (Silva, Almeida, \& Marta-Costa, 2018). Artinya peternak yang menjadikan usaha peternakan sebagia usaha utama diduga akan memiliki nilai efisiensi yang lebih besar dibandingkan dengan peternak yang menajdikan usaha sapi perah sebagai usaha sampingan.

Produksi rumput juga menunjukkan tanda negatif. Sejalan dengan Hansson (2008) meningkatnya luas lahan dapat meningkatkan efisiensi teknik dan ekonomi di Peternakan Sapi Perah Swedia (Kelly et al., 2012).

\section{KESIMPULAN DAN SARAN}

Berdasarkan hasil penelitian yang telah dilakukan dengan menggunakan software Frontier 4.1, menunjukkan bahwa nilai efesiensi usaha peternak di Kecamatan Tanjungsari masih belum efisiensi dikarenkan nilai rata-rata efisiensi teknis dari usaha tersebut kurang dari 1. Berdasarkan nilai tanda koefisien pada masing-masiang parameter jumlah sapi laktasi, pemberian hijauan, dan pemberian konsentrat dapat meningkatkan produksi susu. Faktor yang diduga dapat meningkatkan nilai inefisiensi yaitu pengalaman, total populasi, dan produksi rumput. Faktor-faktor tersebut sebagai 
pertimbangan peternak untuk menjadi usaha yang lebih efisien.

Saran bagi usaha peternak di Kecamatan Tanjungsari yaitu mengoptimalkan pemberian pakan hijauan dan konsentrat, alokasi curahan tenaga kerja keluarga disesuaikan dengan skala usaha. Jika peternak ingin menambah populasi diharapkan melakukan penambahan sapi produktif dan penggunaan lahan untuk menanam rumput dioptimalkan sehingga dapat memenuhi kebutuhan hijauan.

\section{DAFTAR PUSTAKA}

Asmara, A., Purnamadewi, Y. L., \& Lubis, D. (2016). KERAGAAN PRODUKSI SUSU DAN Efisiensi Usaha Peternakan Sapi Perah Rakyat di Indonesia. Jurnal Manajemen Dan Agribisnis, 13(1), 14-25. https://doi.org/10.17358/jma.13.1.1 4

Astuti, M., Widiati, R., \& Suranindyah, Y. Y. (2012). Efisiensi Produksi Usaha Sapi Perah Rakyat (Studi Kasus pada Peternak Anggota Koperasi Usaha Peternakan dan Pemerahan Sapi Perah Kaliurang, Sleman, Yogyakarta) (Production Efficiency of Smallholder Dairy Cattle Farming (Case Study on The Farmer Members of. Buletin Peternakan, 34(1),

64. https://doi.org/10.21059/buletinpete rnak.v34i1.108

Binam, J. N., Tonyè, J., Wandji, N., Nyambi, G., \& Akoa, M. (2004). Factors affecting the technical efficiency among smallholder farmers in the slash and burn agriculture zone of Cameroon. Food Policy, 29(5), 531-545. https://doi.org/10.1016/j.foodpol.20 04.07 .013

Binici, T., Zualuf, C. R., Ozel, R., Sevinc, R., \& Isgin, T. (2013). Assessing production efficiency of dairy farms in Sanliurfa province, Turkey. Journal of Animal and Veterinary Advances, 12(5), 621-624. https://doi.org/10.3923/javaa.2013. 621.624

Coelli, T. (1996). A Guide to FRONTIER Version 4.1: A Computer Program for Stochastic Frontier Production and Cost Function Estimation. CEPA Working Papers, 7, 1-33. https://doi.org/10.1007/BF0015877 4

Girma, H. (2019). Estimation of technical efficiency of dairy farms in central zone of Tigray National Regional State. Heliyon, 5(3), e01322. https://doi.org/10.1016/j.heliyon.20 19.e01322

Johansson, H. (2005). Technical, Allocative, and Economic Efficiency in Swedish Dairy Farms: the Data Envelopment Analysis Versus the Stochastic Frontier Approach. XI:Th International Congress of the European Association of Agricultural Economists (EAAE), 46(0), 1-17.

Kelly, E., Shalloo, L., Geary, U., Kinsella, A., Thorne, F., \& Wallace, M. (2012). The associations of management and demographic factors with technical, allocative and economic efficiency of Irish dairy farms. Journal of Agricultural Science, 150(6), 738-754. https://doi.org/10.1017/S00218596 12000287

Lachaal, L., Chahtour, N., \& Thaber, B. (2002). Technical efficiency of dairy production in Tunisia : a data 
envelopment analysis. New Medit, $3,22-26$.

Nurhayu, A., Ella, A., \& Sariubang, M. (2017). Perbaikan Pakan pada Induk Sapi Perah sedang Laktasi di Kabupaten Enrekang, Sulawesi Selatan. 132-138. https://doi.org/10.14334/pros.semn as.tpv-2017-p.133-139

Saptati, R. A. (2016). Technical Efficiency and Its Determinant Factors of Dairy Farms under Membership of Different Scales of Cooperative in Bogor District, West Java. 232-243. https://doi.org/10.14334/proc.intse m.lpvt-2016-p.232-243

Silva, E., Almeida, B., \& Marta-Costa, A. A. (2018). Efficiency of the Dairy Farms: A Study from Azores (Portugal). European Countryside, 10(4), 725-734. https://doi.org/10.2478/euco-20180040

Siregar, S. B., \& Kusnadi, U. (2004). Peluang Pengembangan Usaha Sapi
Perah di Daerah Dataran Rendah Kabupaten Cirebon. Media Peternakan, 27(2), 63-71.

Sukiyono, K. (2016). Faktor Penentu Tingkat Efisiensi Teknik Usahatani Cabai Merah di Kecamatan Selupu Rejang, Kabupaten Rejang Lebong. Jurnal Agro Ekonomi, 23(2), 176. https://doi.org/10.21082/jae.v23n2. 2005.176-190

Syahyuti, N. (2016). Relevansi Konsep dan Gerakan Pertanian Keluarga (Family Farming) serta Karakteristiknya di Indonesia. Forum Penelitian Agro Ekonomi, $34(2)$, 87. https://doi.org/10.21082/fae.v34n2. 2016.87-101

Yusdja, Y. (2005). Kebijakan ekonomi industri agribisnis sapi Perah di Indonesia. Jurnal Analisis Kebijakan Pertanian, 3(70), 1-11. 